\title{
Crop damage of Eriotheca gracilipes (Bombacaceae) by the Blue-Fronted Amazon (Amazona aestiva, Psittacidae), in the Brazilian Cerrado
}

\author{
Ragusa-Netto, J. ${ }^{a *}$

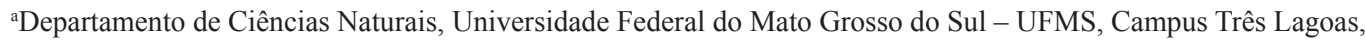 \\ Av. Ranulpho Marques Leal, 3484, CP 210, CEP 79610-100, Três Lagoas, MS, Brazil \\ *e-mail: jragusanetto@yahoo.com
}

Received: April 4, 2013 - Accepted: August 29, 2013

(With 3 figures)

\begin{abstract}
Seed predation has major effects on the reproductive success of individuals, spatial patterns of populations, genetic variability, interspecific interactions and ultimately in the diversity of tree communities. At a Brazilian savanna, I evaluated the proportional crop loss of Eriotheca gracilipes due the Blue-Fronted Amazon (Amazona aestiva) during a fruiting period. Also, I analyzed the relationship between proportional crop loss to Amazons and both fruit crop size and the distance from the nearest damaged conspecific. Trees produced from 1 to 109 fruits, so that Amazons foraged more often on trees bearing larger fruit crop size, while seldom visited less productive trees. Moreover, the relationship between fruit crop sizes and the number of depredated fruits was significant. However, when only damaged trees were assessed, I found a negative and significant relation between fruit crop size and proportional crop loss to Blue-Fronted Amazons. Taking into account this as a measure more directly related to the probability of seed survival, a negative density dependent effect emerged. Also, Amazons similarly damaged the fruit crops of either close or distant neighboring damaged trees. Hence, in spite of Blue-Fronted Amazons searched for E. gracilipes bearing large fruit crops, they were swamped due to the presence of more fruits than they could eat. Moderate seed predation by Blue-Fronted Amazons either at trees with large fruit crops or in areas where fruiting trees were aggregated implies in an enhanced probability of E. gracilipes seed survival and consequent regeneration success.
\end{abstract}

Keywords: density dependency, frugivory, tree population, predator satiation, seed predation.

\section{Predação pré-dispersão de sementes de Eriotheca gracilipes (Bombacaceae), pelo Papagaio verdadeiro (Amazona aestiva, Psittacidae) no Cerrado brasileiro}

\begin{abstract}
Resumo
Avaliei durante um episódio de frutificação, no cerrado brasileiro, o impacto da predação de sementes, pelo Papagaio verdadeiro (Amazona aestiva), sobre as cargas de frutos da paineira do cerrado (Eriotheca gracilipes). Também, analisei as relações entre a taxa predação e tanto o tamanho das cargas de frutos, quanto à distância da E. gracilipes mais próxima predada. As ávores produziram de 1 a 109 frutos, sendo que os papagaios forragearam frequentemente em árvores com grandes cargas, enquanto raramente visitaram árvores com poucos frutos. Além disso, a relação entre tamanho da carga e número de frutos predados foi significativa. No entanto, a relação entre quantidade e proporção de frutos predados pelos Papagaios verdadeiros foi negativa e significativa. Considerando que a proporção de frutos predados é uma medida estreitamente relacionada às chances de sobrevivência das sementes, a predação pelos papagaios foi negativamente dependente da densidade. Apesar dos papagaios visitarem árvores com grandes cargas de frutos, foram saciados devido a presença de cargas superiores ao potencial de predação. Além disso, os papagaios danificaram igualmente as cargas de frutos tanto de árvores próximas quanto distantes entre si. O reduzido impacto pelos papagaios tanto sobre as grandes cargas de frutos quanto em áreas adensadas de E. gracilipes, implica em elevadas probabilidades de sobrevivência das sementes e respectiva chance de regeneração de E. gracilipes.
\end{abstract}

Palavras-chave: densidade dependente, frugivoria, população arbórea, saciação de predadores, predação de sementes. 


\section{Introduction}

Seed predation is one of the main processes limiting initial plant recruitment (Janzen, 1971; Wenny, 2000). During the earliest stage of the plant life cycle this process has a direct effect on plant reproductive success and plays a significant role in determining the spatial structure and dynamics of plant populations (Janzen, 1971; Hulme, 1997; Nathan and Muller-Landau, 2000). In the Neotropics much of the observed tree diversity results from mechanisms that prevents dominance by an individual species. Janzen (1970) postulated that negative interactions between plants and animals are strongly related to the maintenance of plant diversity. Janzen's model predicts an enhancement of seed predation rate according to seed density or proximity to a reproductive tree. Distance- or density-dependent mortality during recruitment leads to a decreased probability that a species will replace itself at a site and promotes maintenance of diversity (Janzen, 1970; Clark and Clark, 1984; Forget et al., 2000). In fact, seed predation may be either positively or negatively densitydependent and the pattern can be expected to vary with the relative abundance of seeds and their predators. During periods of reduced food availability seed predation tends to be positively density-dependent. On the other hand, plentiful seed availability might swamp seed predators and a negative density-dependent response may occur (Janzen, 1970; Manson et al., 1998). In this respect, a canopy or a collection of neighboring canopies bearing enhanced fruit crop sizes tend to cause predator satiation, which consequence is an improved seed survival within a dense seed patch (Augspurger, 1981; Ghazoul and Satake, 2009). Therefore, seed success is strongly influenced by pre-dispersal seed predators, and negative density-dependent effect on seed predation or predator satiation will determine the fecundity level of individual plants (Forget et al. 2000; Ghazoul and Satake, 2009).

Fruit production is variable in time and space, which may influence the intensity of exploitation by pre-dispersal seed predators, such as parrots (Van Schaik et al., 1993). These birds are well known by tracking the erratic pattern of fruit availability (Renton, 2001, Moegenburg and Levey, 2003; Ragusa-Netto, 2007a, b, 2008); consequently, the proportional crop loss to them may vary according to food resources availability (Schupp, 1988, 1990; Peres, 1991). In fact, parrots are assumed as important seed predators due to their large and mobile populations (Terborgh et al., 1990). They often damage around $10 \%$ of fruit crops of Neotropical tree species (Janzen, 1972; Howe, 1980; Trivedi et al., 2004; Silva, 2005), although total crop loss may be higher for some tree species (Francisco et al., 2002, 2008; Haugaasen, 2008; Villaseñor-Sanchez et al., 2010; Ragusa-Netto, 2011). Tree species from dry areas often exhibit clumped distribution (Hubbell, 1979), besides brief and pronounced fruiting patterns, which consequence is a variable fruit patch dynamics (van Schaik et al., 1993). In this context, parrots may be attracted to individual fruit crops as well as to a collection of neighboring fruiting trees (Coates-Estrada et al., 1993; Cameron and Cunningham, 2006; Villaseñor-Sanchez et al., 2010, Ragusa-Netto, 2011). In this respect, the damage caused by parrots to individual fruit crop may be density-dependent (Francisco et al., 2008; Ragusa-Netto, 2011), although an inversely negative densitydependent seed predation may also occur (Trivedi et al., 2004; Villaseñor-Sanchez et al., 2010).

Few studies focused on fruit crop damage by Amazons parrots (Amazona spp.), but see (Howe 1980, CoatesEstrada et al., 1993, Villaseñor-Sanchez et al., 2010). Despite of population decline in many species, some of them are yet common, exhibiting wide distribution (Collar, 1997; Sick, 1997). Hence, locally common Amazons might to impact tree species populations by severely damaging their fruit crops (Villaseñor-Sanchez et al., 2010). Also, these pre-dispersal seed predators often search for clumps of fruiting trees, instead of only an individual fruit crop, in principle to maximize foraging efficiency (CoatesEstrada et al., 1993; Villaseñor-Sanchez et al., 2010). At dry areas, Bombacaceae seeds are among common Amazon's foods (Renton, 2001; Ragusa-Netto, unpublished), and two recent studies reported high seed predation rates by parakeets on two Bombacaceae species at small Cerrado (Brazilian savanna) remnant (Francisco et al., 2002; Francisco et al., 2008). In one of them (Francisco et al., 2008), Eriotheca gracilipes (Schum.) Robyns experienced high seed predation rates, which was significantly affected by individual fruit crop size, while conspecific fruiting trees surrounding the studied individuals were unrelated to predation rate. Here, I describe the impact of the BlueFronted Amazon (Amazona aestiva, Linnaeus, 1758) on Eriotheca gracilipes (Schum.) Robyns fruit crops at large and important Cerrado reserve (Emas National Park), where both Blue-Fronted Amazon and Eriotheca gracilipes are yet common. Particularly, I assessed the proportional crop loss of E. gracilipes trees to Amazons and further, I analyzed the relationships between proportional crop loss to Amazons and both fruit crop size and the distance from the nearest damaged conspecific tree.

\section{Material and Methods}

Study area. This study was carried out at the Emas National Park (hereafter ENP), which is in the Cerrado core region with an area of 133,000 ha, located in the Brazilian Central Plateau south western of the Goiás State $\left(17^{\circ} 19^{\prime}-18^{\circ} 28^{\prime} \mathrm{S}\right.$ and $52^{\circ} 39^{\prime}-53^{\circ} 10^{\prime} \mathrm{W}$, altitude $900-1100 \mathrm{~m})$. Data collection was developed in the southern part of ENP ( $18^{\circ} 15^{\prime} \mathrm{S}$ and $52^{\circ} 53^{\prime} \mathrm{W}$, altitude $\left.900 \mathrm{~m}\right)$. The climate is marked seasonal with a wet (October-March), and a pronounced dry season (April-September). Annual rainfall is approximately $1,500 \mathrm{~mm}(70 \%$ in the wet season), and mean annual temperature lies around $24.6^{\circ} \mathrm{C}$.

The vegetation in the area is a mosaic of gallery forest, palm (Mauritia flexuosa) stands, and the dominant Cerrado (93\% of the area), which exhibit a gradient including from open fields to dense wood vegetation. However, $70 \%$ of 
the Cerrado is savanna-like habitat, in which trees (2-6 m in height) are interspersed with open grassy areas. During the dry season tree species shed their leaves, mainly in the late dry season (August and September). The richest plant families are Asteraceae, Fabaceae, Poaceae, and Myrtaceae (for details see Batalha and Martins (2002)). In the ENP Cerrado, E. gracilipes is a deciduous tree 1-8 $\mathrm{m}$ height. The fruits are dehiscent capsules including seeds covered with cotton-like fibers for wind dispersion (Lorenzi, 1998).

Field procedures. To sample trees to evaluate fruit production and crop damage by Amazons, I used six 4$\mathrm{Km}$-long permanent access trails, in which I marked with aluminum numbered tags all individuals of E. gracilipes located within a $3.0 \mathrm{~m}$ margin on either sides of the trails, and with a diameter at the base equal or greater than 4 $\mathrm{cm}$ (mature trees). This sample included 90 individuals (9-23 per trail), which I monitored for fruit production and crop damage from early June to late September 2004. At every two weeks I checked fruit crop size by counting fruits present at every crown and assessed crop damage by inspecting the ground under the trees to count both fallen damaged and undamaged fruits (the rigid capsules/ exocarps lasts 3-5 months to completely decay). I also checked fallen fruits for the presence of pierce marks caused by insect seed predators, because total seed damage might be underestimated if only parrot seed predation was sampled (Villaseñor-Sanchez et al., 2010). The inspection of a given tree finished when all of the fruits were destroyed or matured to the point they open to expose seeds. In this respect, as I thorough checked the ground under fruiting trees several times, I am confident that no fallen fruit was missed. Then, I measure the distance to the nearest conspecific which also exhibited depredated fruits. Amazons were the putative seed predators because locals often observed then feeding on E. gracilipes fruits. Also, while parakeets foraged on fruits without to remove them from the peduncle (Francisco et al., 2008), Amazons detached them to eat seeds. After that they drop the fruit remains under the tree crown. To confirm my observation, from July to September, I sampled parrots feeding on E. gracilipes trees by direct observations (monthly $12 \mathrm{~h}$, from 06:00 to 09:00 h), while walking the permanent access trails mentioned above. Whenever at least a parrot was detected feeding on E. gracilipes fruits I recorded the species, number of individuals, and the time and date. From 5 trees, I collected fruits with different number of seeds to measure both fruit and seed size.

Data analyzes. Because Amazons perform daily trips from communal roots to feeding areas (Berg and Angel, 2006; Matuzak and Brightsmith, 2007; Ragusa-Netto, 2011), where the density of fruit patches may vary, and taking into account that predators should concentrate their activities in sites where foraging success is expected (Schupp, 1988), I tested the relationship between individual fruit crop size and the chance of crop damage by Amazons through logistic regression, in which individual fruit crop size was coded as 0 (undamaged), or 1 (damaged by amazons). To analyze the relationship between fruit crop size and either the number of damaged fruits or proportional crop loss to Amazons, as well as the relationship between proportional crop loss and the distance to the nearest depredated conspecific, I applied linear regression. The dependent variables were total number and proportion of seeds predated by Amazons in each tree. Independent variables were the initial number of fruits in the tree estimated by visual counts, and the distance $(\mathrm{m})$ from the nearest depredated conspecific from the focal tree. Original data were transformed to $\log _{10}$, while the proportion of fruit crop size lost to Amazons was Box-Cox transformed to achieve normality and linearity. I assumed the number of depredated fruits as a proxy of the number of depredated seeds. If some seeds remained inside attacked fruits, they would presumably die (Janzen, 1970).

\section{Results}

Trees bore fruits from June to early October. During August and September developed unripe fruits exhibiting an ovoid shape had from 55.3 to $77.8 \mathrm{~mm}$ in length (mean \pm SD: $63.2 \pm 6.5 \mathrm{~mm}$ ), and from 39.7 to 48.3 in diameter $(42.8 \pm 2.5 \mathrm{~mm}, \mathrm{n}=11)$. They had 9 to 23 seeds $(16.45 \pm 4.13, \mathrm{n}=11)$, which had an almost spherical shape of $8.73 \pm 0.63 \mathrm{~mm}$ in length and $0.27 \pm 0.08 \mathrm{~g}$ in weight $(\mathrm{n}=40)$. In 2004 fruiting trees bore from 1 to 109 fruits $(17.9 \pm 22.3$ fruits, total $=1612$ fruits, $n=90$ trees $)$. Only 30 trees had a fruit crop size higher than the average crop size. Tree size (diameter at breast height) ranged from 4 to $26 \mathrm{~cm}(9.9 \pm 5.1 \mathrm{~cm})$ and was positively correlated with fruit crop size $(\mathrm{r}=0.55, \mathrm{p}<0.0001, \mathrm{n}=90$ trees $)$.

Several psittacid species occurred in the ENP (Ara ararauna, Linnaeus, 1758; Alipiopsitta xanthops, Spix, 1824; Aratinga aurea, Gmelin, 1788; Diopsittaca nobilis, Linnaeus, 1758; and Orthopsittaca manilata, Boddaert, 1783). However, I detected in 2004, during $36 \mathrm{~h}$ of observations, 32 Blue-Fronted Amazons (4 solitary individuals and 14 pairs), feeding on E. gracilipes seeds. No other parrot species foraged on these fruits during my observations in this year. Besides that, fallen fruits had no pierce marks caused by insects. Blue-Fronted Amazons took the capsules with the bill, hold them with one foot and opened the fruits with their beaks and tearing away pieces of the wall until expose the seeds for consumption. Then, Amazons drop capsules beneath the tree crowns. Even if some seeds escaped from depredation by Amazons the remaining seeds decomposed. Besides that, most of those seeds would be immature because fruits were damaged while still unripe. Amazons foraged on 37 trees $(41 \%, n$ $=90)$, damaging a total of 254 fruits $(15.76 \%$ of total). Trees that escaped from depredation bore from 1 to 109 fruits $(13.47 \pm 17.94, \mathrm{n}=53$ trees $)$, while damaged trees bore from 2 to 106 fruits $(23.68 \pm 26.31, \mathrm{n}=37$ trees $)$. Amazons damaged from $2.5 \%$ to $100 \%$ of individual fruit crop size $(13.42 \pm 23.01 \%, \mathrm{n}=37$ trees $)$. In fact, most trees $(61.1 \%, n=90)$ lost to parrots less than $5 \%$ of individual fruit crop size. 
Amazons foraged more often on those trees bearing large fruit crop size (logistic regression, $\chi 2=9.94, p=0.002$, Figure 1). Following this trend, the relationship between individual fruit crop size and number of depredated fruits was positive and significant $\left(\mathrm{r}^{2}=0.210, \mathrm{t}=4.823\right.$, $\mathrm{p}=0.0001, \mathrm{n}=90)$. This correlation increases when only damaged trees were analyzed $\left(r^{2}=0.350, t=4.342\right.$, $\mathrm{p}=0.0004, \mathrm{n}=37$ ). However, when individual fruit crop size and proportional crop loss of depredated trees were focused a negative and significant relationship emerged $\left(r^{2}=0.131, t=-2.297, p=0.03, n=37\right.$, Figure 2). Also, the proportional crop loss to Amazons was unrelated to the distance of the nearest damaged conspecific $\left(r^{2}=0.001\right.$, $\mathrm{t}=-0.196, \mathrm{p}=0.841, \mathrm{n}=37$, Figure 3 ).

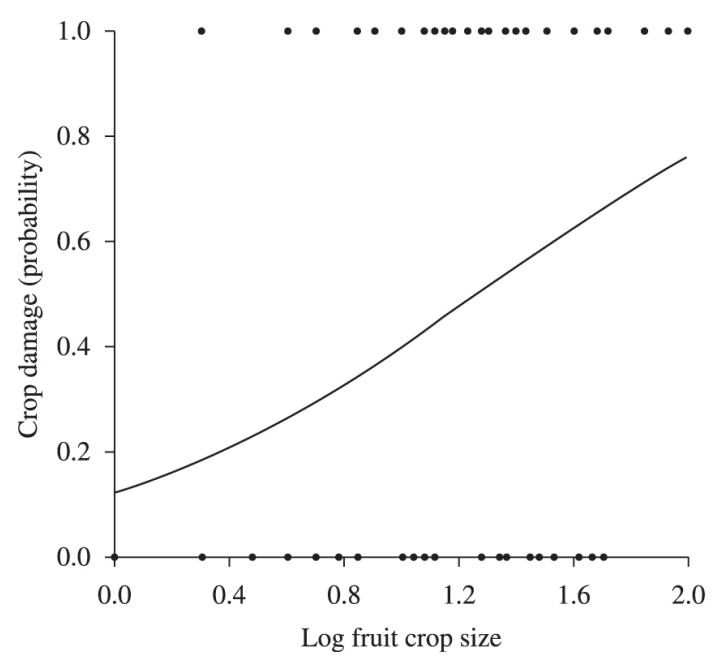

Figure 1. Chance of crop damage by Blue-Fronted Amazons in relation to Eriotheca gracilipes individual fruit crop size $\left(\log _{10}\right.$ transformed; Emas National Park, State of Goiás, Brazil).

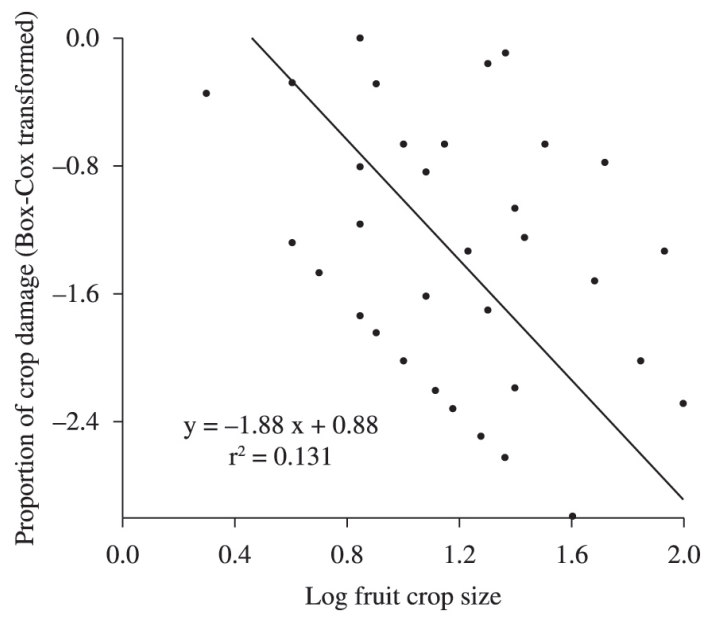

Figure 2. Proportional crop damage in Eriotheca gracilipes caused by Blue-Fronted Amazons in relation to individual fruit crop size $\left(\log _{10}\right.$ and Box-Cox transformed; Emas National Park, State of Goiás, Brazil).

\section{Discussion}

The Blue-Fronted Amazon is widely distributed in South America occurring either in dense (dry and gallery forests), or semi-open seasonal areas (Caatinga and Cerrado). However, detailed studies on their diet continue scarce (but see Ragusa-Netto and Fecchio, 2006). These parrots often forage on seeds from dry fruits during the prolonged dry season of their habitats (Collar, 1997; Sick, 1997; RagusaNetto and Fecchio, 2006). In fact, in the Cerrado, seeds from dry fruits, including those from $E$. gracilipes, formed $62 \%$ of their diet during a two years period (Ragusa-Netto, unpublished). Besides that, they often forage on common plant groups from the Cerrado, mainly on Leguminosae, Annacardiace, Sapotaceae, Bombacaceae, and Vochysiaceae (Ragusa-Netto, unpublished). Therefore, in principle, as generalist seed predators they are likely to exploit dense available food resources.

Blue-Fronted Amazons damaged a moderate proportion (13.4\%) of E. gracilipes fruit crops. Other parrot species also caused a similar crop loss to trees they attacked (Janzen, 1972; Howe, 1980; Trivedi et al., 2004; Silva, 2005). On the other hand, two other Amazons (A. autumnalis, Linnaeus, 1758, Coates-Estrada et al., 1993; and A. finschi, Sclater, 1864, Villaseñor-Sanchez et al. 2010), and a macaw (Ara ararauna, Ragusa-Netto, 2011), depredated $40-50 \%$ of fruit crops, while total crop loss was higher for some tree species (Haugaasen, 2008; Francisco et al., 2008). The damage on E. gracilipes fruit crops caused by Blue-Fronted Amazons in the ENP contrasted with the higher pre-dispersal seed predation (67\%) suffered by this tree species at small Cerrado remnant caused by parakeets. The high pre-dispersal seed predation by parrots in fragmented habitats might be a consequence of food-resource limitation to parrots (Francisco et al.,

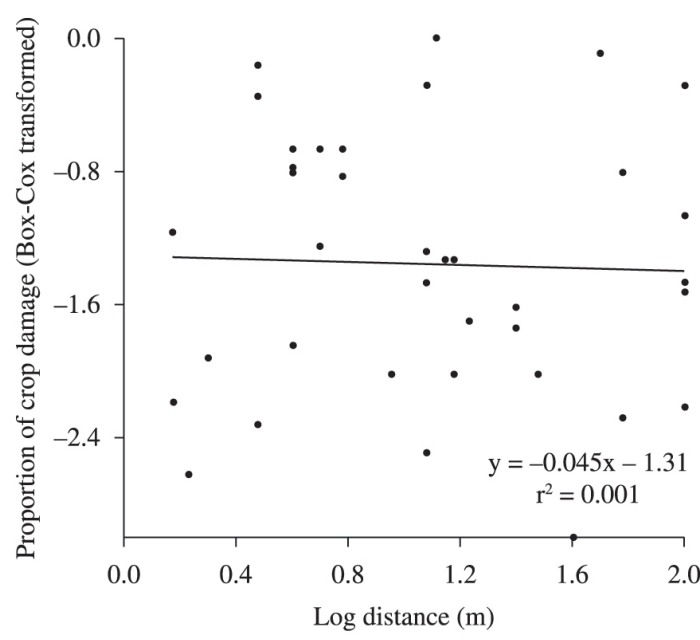

Figure 3. Proportional crop damage in Eriotheca gracilipes caused by Blue-Fronted Amazons in relation to the distance from the nearest damaged conspecific tree $\left(\log _{10}\right.$ and BoxCox transformed; Emas National Park, State of Goiás, Brazil). 
2008). However, this also occurred at preserved areas where Haugaasen (2008) reported macaws damaging 62\% of the fruit crop of Couratari guianensis in Amazonian forest. The reduced number of studies, which often focused narrow temporal and spatial scales (but see Ragusa-Netto, 2011), might have underestimate the impact of parrots on pre-dispersal seed loss. In this respect, either a positive or negative density-dependent response may conform to the above crop damage rates caused by parrots.

My results do not support the hypothesis that increasing fruit crop size leads to increasing seed predation rates. In spite of the propensity of Amazons to forage on trees bearing large fruit crops, the relationship between fruit crop size and proportional crop damage, a measure more directly related to the probability of seed survival, suggest a negative density-dependent effect. This was more clear when undamaged trees were removed from analyzes, as a substantial number of trees $(n=53)$ bearing from small to large fruit crops escaped from predation. The results indicate higher survival rates to seeds within large fruit crops due to satiation of Blue-Fronted Amazons. Parrots are seed predators which impact on fruit crops is related to factors such as foraging behavior, home range, habitat preference, predator avoidance, and the availability of other resources (Francisco et al., 2008; Villaseñor-Sanchez et al., 2010, Ragusa-Netto, 2011). Therefore, parrots may not respond in a consistent manner to a gradient in seed density (Trivedi et al. 2004). For example, VillaseñorSanchez et al. (2010), found that the rate of pre-dispersal seed predation by the Lilac-Crowned Amazon (A. finschi) was significantly greater in dense fruiting patches, and was not related to fruit abundance of the focal trees. In principle, parrots can memorize the location of adequate fruit crops, so that the probability of seed predation tends to be higher at larger fruit crops because they often return to forage on favorable fruit patches. Moreover, presumably, parrots cue on the movement patterns of other parrots by watching their activities, or hearing sounds of their feeding activities. However, in the present study the consequence was survival advantage to fruits within large fruit crops. This was, in principle, due to predator satiation when the crown contained more fruits than the predator could eat. This also might explain the absence of relationship between proportional crop loss to Amazons and distance of neighbor depredated conspecific, which tend to be positive when density dependent seed predation occurred (Villaseñor-Sanchez et al., 2010; Ragusa-Netto, 2011).

It is important take into account that in the ENP, which includes a representative Cerrado flora (Batalha and Martins, 2002), a large number of tree species bore fruits simultaneously to E. gracilipes (Ragusa-Netto, unpublished). Among them were other six species (Xylopia emarginata Mart., Eriotheca pubescens Schott et Endl., Anadenanthera falcata (Benth.) Speg., Dimorphandra mollis Benth., Stryphnodendron adstringens (Mart.) Coville, Styrax ferrugineus Nees \& Mart.), extensively exploited by Blue-Fronted Amazons (Ragusa-Netto, unpublished). Heterogeneity both in plant density and composition may explain differences in the level of resources for parrots. For this generalist parrot the difference in resource abundance may have consequences for seed fate of $E$. gracilipes, because the foraging activity of Amazons may be influenced by the total amount of resources available, rather than only by a specific fruit density (Ragusa-Netto, 2007b). The greater survivorship observed in trees with larger fruit crops might then also be due to the greater global resource abundance at ENP in this period. Thus, if the satiation hypothesis seems to apply at the population level (see above), it may still be of importance at the community level, as parrots may be satiated by the whole fruit abundance. This is consistent because consumer satiation seems to occur during the whole fruit-peak. The present results point out to the satiation hypotheses at the population scale. However, it is important to consider the possibility that predator satiation might be acting at the community level, because Amazons also foraged on other tree species while eating $E$. gracilipes seeds. This emphasizes the necessity of conducting ecological studies at different spatial and temporal scales, and at different levels of organization (individual, population and community) as already noted by Schupp (1992). Also, the influence of resource abundance on the intensity of seed predation by mobile, canopy vertebrates has implications for tree community dynamics. Moderate seed predation by BlueFronted Amazons either at trees with large fruit crops or in areas where fruiting trees are aggregated implies in an enhanced probability of $E$. gracilipes seed survival and consequent regeneration success.

\section{Acknowledgements}

I am grateful to Gabriel Borges (IBAMA) for logistical support at the Emas National Park. The constructive comments of Rodrigo F. Fadini improved an early version of this study. Financial support was provided by FUNDECT, $\mathrm{CNPq}$, and PROPP/UFMS.

\section{References}

AUGSPURGER, CK., 1981. Reproductive synchrony of a tropical shrub: experimental studies on effects of pollinators and seed predators on Hybanthus prunifolius (Violaceae). Ecology, vol. 62, no. 3, p. 775-788. http://dx.doi.org/10.2307/1937745.

BATALHA, MA. and MARTINS, FR., 2002. The vascular flora of the cerrado in Emas National Park (Goiás, Central Brazil). Sida, vol. 20, p. 295-311.

BERG, KS. and ANGEL, RR., 2006. Seasonal roosts of Redlored Amazons in Ecuador provide information about population size and structure. Journal of Field Ornithology, vol. 77, no. 2, p. 95-103. http://dx.doi.org/10.1111/j.1557-9263.2006.00028.x.

CAMERON, M. and CUNNINGHAM, RB., 2006. Habitat selection at multiple spatial scales by foraging Glossy Blackcockatoos. Austral Ecology, vol. 31, no. 5, p. 597-607. http:// dx.doi.org/10.1111/j.1442-9993.2006.01591.x.

CLARK, DA. and CLARK, DB., 1984. Spacing dynamics of a tropical rain forest tree: evaluation of the Janzen-Connell model. American Naturalist, vol. 124, no. 6, p. 769-788. http://dx.doi. org/10.1086/284316. 
COATES-ESTRADA, R., ESTRADA, A. and MERITT JUNIOR, D., 1993. Foraging by parrots (Amazona autumnalis) on fruits of Stemmadenia donnell-smithii (Apocynaceae) in the tropical rain forest of los Tuxtlas, Mexico. Journal of Tropical Ecology, vol. 9, p. 121-124. http://dx.doi.org/10.1017/S0266467400007070.

COLLAR, NJ., 1997. Family Psittacidae (parrots). In Del HOYO, J., ELLIOT, A. and SARGATAL, J. (Eds.). Handbook of the birds of the world: Sangrouse to cuckoos. Spain: Linx editions Barcelona. p. 280-477. vol. 4.

FORGET, PM., MILLERON, T., FEER, F., HENRY, O. and DUBOST, G., 2000. Effects of dispersal pattern and mammalian herbivores on seedling recruitment for Virola michelii (Myristicaceae) in French Guiana. Biotropica, vol. 32, no. 3, p. 452-462. http:// dx.doi.org/10.1111/j.1744-7429.2000.tb00492.x.

FRANCISCO, MR., LUNARDI, VO. and GALETTI, M., 2002. Massive seeds predation of Pseudobombax grandiflorum (Bombacaceae) by parakeets Brotogeris versicolurus (Psittacidae) in a forest fragment in Brazil. Biotropica, vol. 34, no. 4, p. 613615. http://dx.doi.org/10.1111/j.1744-7429.2002.tb00582.x.

FRANCISCO, MR., LUNARDI, VO., GUIMARÃES, PR Jr. and GALETTI, M., 2008. Factors affecting seed predation of Eriotheca gracilipes (Bombacaceae) by parakeets in a cerrado fragment. Acta Oecologica, vol. 33, no. 2, p. 240-245. http:// dx.doi.org/10.1016/j.actao.2007.11.002.

GHAZOUL, J. and SATAKE, A., 2009. Nonviable seed set enhances plant fitness: the sacrificial sibling hypothesis. Ecology, vol. 90, no. 2, p. 369-377. http://dx.doi.org/10.1890/07-1436.1. PMid:19323221

HAUGAASEN, T., 2008. Seed predation of Couratari guianensis (Lecythidaceae) by macaws in central amazonia, Brazil. Ornitologia Neotropical, vol. 19, p. 321-328.

HOWE, HF., 1980. Monkey dispersal and waste of a neotropical fruit. Ecology, vol. 61, no. 4, p. 944-959. http://dx.doi. org/10.2307/1936763.

HUBBELL, SP., 1979. Tree dispersion, abundance, and diversity in a tropical dry forest. Science, vol. 203, no. 4387, p. 1299-1309. http://dx.doi.org/10.1126/science.203.4387.1299. PMid:17780463

HULME, PE., 1997. Post-dispersal seed predation and the establishment of vertebrate dispersed plants in Mediterranean scrublands. Oecologia, vol. 111, no. 1, p. 91-98. http://dx.doi. org/10.1007/s004420050212.

JANZEN, D., 1970. Herbivores and the number of tree species in tropical forests. American Naturalist, vol. 104, no. 940, p. 501-528. http://dx.doi.org/10.1086/282687.

JANZEN, D., 1971. Seed predation by animals. Annual Review of Ecology and Systematics, vol. 2, no. 1, p. 465-492. http://dx.doi. org/10.1146/annurev.es.02.110171.002341.

JANZEN, D., 1972. Escape in space by Sterculia apetala seeds from the bug Disdercus fasciatus in a Costa Rica deciduous forest. Ecology, vol. 53, no. 2, p. 350-361. http://dx.doi.org/10.2307/1934092.

LORENZI, H., 1998. Árvores brasileiras: manual de identificação e cultivo de plantas arbóreas nativas do Brasil. Nova Odessa: Editora Plantarum. 320 p. vol. 2.

MANSON, RH., OSTFELD, RS. and CANHAM, CD., 1998. The effects of tree seed and seedling density on predation rates by rodents in old fields. Ecoscience, vol. 5, p. 183-190.

MATUZAK, GD. and BRIGHTSMITH, DJ., 2007. Roosting of Yellow $\square$ naped Parrots in Costa Rica: estimating the size and recruitment of threatened populations. Journal of Field Ornithology, vol. 78, no. 2, p. 159-169. http://dx.doi.org/10.1111/j.15579263.2007.00099.x.

MOEGENBURG, SM. and LEVEY, DJ., 2003. Do frugivores respond to fruit harvest? An experimental study on short-term responses. Ecology, vol. 84, no. 10, p. 2600-2612. http://dx.doi. org/10.1890/02-0063.

NATHAN, R. and MULLER-LANDAU, HC., 2000. Spatial patterns of seed dispersal, their determinants and consequences for recruitment. Trends in Ecology \& Evolution, vol. 15, no. 7, p. 278-285. http://dx.doi.org/10.1016/S0169-5347(00)01874-7. PMid:10856948

PERES, CA., 1991. Seed predation of Cairiniana micrantha (Lecythidaceae) by brown capuchin monkeys in Central Amazonia. Biotropica, vol. 23, no. 3, p. 262-270. http://dx.doi. org/10.2307/2388203.

RAGUSA-NETTO, J., 2007a. Feeding ecology of the Greencheeked parakeet (Pyrrhura molinae) in dry forests in western Brazil. Brazilian journal of biology $=$ Revista brasleira de biologia, vol. 67, no. 2, p. 243-249. http://dx.doi.org/10.1590/ S1519-69842007000200009. PMid:17876434

RAGUSA-NETTO, J., 2007b. Nectar, fleshy fruits and the abundance of parrots at a gallery forest in the southern Pantanal (Brazil). Studies on Neotropical Fauna and Environment, vol. 42, no. 2, p. 93-99. http://dx.doi.org/10.1080/01650520600979643.

RAGUSA-NETTO, J., 2008. Yellow-Chevroned Parakeet (Brotogeris chiriri) abundance and canopy foraging at a dry forest in western Brazil. Studies on Neotropical Fauna and Environment, vol. 43, no. 2, p. 99-105. http://dx.doi.org/10.1080/01650520701510859.

RAGUSA-NETTO, J., 2011. Pre-dispersal seed predation by Blue-and-Yellow Macaw (Ara ararauna, Psittacidae), on fruit crops of the Pequi (Caryocar brasiliense, Caryocariaceae), in the Brazilian cerrado. Ornitologia Neotropical, vol. 22, p. 329-338.

RAGUSA-NETTO, J. and FECCHIO, A., 2006. Plant food resources and the diet of a parrot community in a gallery forest of the south Pantanal (Brazil). Brazilian Journal of Biology, vol. 66 , no. 4, p. 1021-1032. http://dx.doi.org/10.1590/S151969842006000600008

RENTON, K., 2001. Lilac-crowned Parrot diet and food resource availability: resource tracking by a parrot seed predator. The Condor, vol. 103, no. 1, p. 62-69. http://dx.doi.org/10.1650/00105422(2001)103[0062:LCPDAF]2.0.CO;2.

SCHUPP, EW., 1988. Factors affecting post-dispersal seed survival in a tropical forest. Oecologia, vol. 76, p. 525-530.

SCHUPP, EW., 1990. Annual variation in seed fall, post dispersal predation and recruitment of a neotropical tree. Ecology, vol. 71, no. 2, p. 504-515. http://dx.doi.org/10.2307/1940304.

SCHUPP, EW., 1992. The Janzen-Connell model for tropical tree diversity: population implications and the importance of spatial scale. American Naturalist, vol. 140, no. 3, p. 526-530. http:// dx.doi.org/10.1086/285426. PMid:19426055

SICK, H., 1997. Ornitologia Brasileira. Nova Fronteira: Rio de Janeiro.

SILVA, PA., 2005. Predação de sementes pelo maracanã-nobre (Diopsittaca nobilis, Psittacidae) em uma planta exótica Melia azedarach, Meliaceae) no oeste do Estado de São Paulo, Brasil. Revista Brasileira de Ornitologia, vol. 13, p. 183-185. 
TERBORGH, J., ROBINSON, SK., PARKER III, TA., MUNN, CA. and PIERPONT, N., 1990. Structure and organization of the Amazonian forest bird community. Ecological Monographs, vol. 60, no. 2, p. 213-238. http://dx.doi.org/10.2307/1943045.

TRIVEDI, MR., CORNEJO, FH. and WATKINSON, AR., 2004. Seed predation on Brazil nuts (Berthollethia excelsa) by macaws (Psittacidae) in Madre de Dios, Peru. Biotropica, vol. 36, p. 118-122.

VAN SCHAIK, CP., TERBORGH, JW. and WRIGHT, SJ., 1993. The phenology of tropical forests, adaptive significance, and consequences for primary consumers. Annual Review of
Ecology and Systematics, vol. 24, no. 1, p. 353-377. http://dx.doi. org/10.1146/annurev.es.24.110193.002033.

VILLASEÑOR-SÁNCHEZ, EI., DIRZO, R. and RENTON, K., 2010. Importance of lilac-crowned parrot in pre-dispersal seed predation of Astronium graveolens in a Mexican tropical dry forest. Journal of Tropical Ecology, vol. 26, no. 2, p. 227-236. http://dx.doi.org/10.1017/S0266467409990447.

WENNY, DG., 2000. Seed dispersal, seed predation, and seedling recruitment of a neotropical montane tree. Ecological Monographs, vol. 70, no. 2, p. 331-351. http://dx.doi.org/10.1890/00129615(2000)070[0331:SDSPAS]2.0.CO;2. 